\title{
CLINICAL, BIOCHEMICAL, AND HAEMODYNAMIC STUDIES IN MAN DURING REFRACTORY HYPOTENSION*
}

\author{
LeONARD C. JENIINS, B.A., M.D., C.M., F.R.C.P.(C), W. A. DodDS, M.D., AND \\ H. B. Graves, B.A., M.D., C.M., F.H.C.P.(C)
}

TEE MAJORTY of human shock problems are easily handled with replacement of effective circulating blood volume or by repair of some easily recognized and correctable defect. In a small but significant number of patients, hypotension develops which is refractory to the usual resuscitative measures. The mortality is high. Such patients are considered to have blood, plasma, or extracellular fluid volumes restored to normal before they are termed "refractory" to therapy. These patients have usually received intravenous vasopressors, corticosteroids, and massive doses of antibiotics, as a last resort in a desperate effort to restore blood pressure and tissue perfusion. It is in this group of refractory hypotensive or irreversible shock patients that current problems in the treatment of shock exist.

We have been impressed by the similarity between open-heart cardiopulmonary bypass patients presenting postoperatively in refractory hypotensive states and those patients in shock from haemorrhage, trauma, or severe infection. The cardiopulmonary bypass patient has received meticulous monitoring in the postoperative period. As a result, much information has been obtained in these patients that has led to precise, successful treatment of defects contributing to the refractory hypotensive situation. It seemed that other patients presenting / with refractory hypotension would also benefit from such careful study. In addition, it was hoped that information gained in some aspects of the pathophysiological sequence occurring in man during refractory shock might also provide a basis for rational evaluation of various forms of chemical therapy at present advocated in the management of shock.

Reçently, therefore, we have been studying some biochemical and haemodynamic alterations in postoperative patients with severe refractory hypotension, in imminent danger of death. We have selected four of these patients to illustrate our findings and to exemplify some useful concepts that were found beneficial in the management of these patients.

\section{METHODS}

All the patients studied had hypotension that was refractory to initial blood volume restoration and in many instances to other therapeutic measures. Intravenous vasopressors had already been started in all patients, before we had / seen the patient, in an attempt to maintain some degree of blood pressure.

From the Department of Anaesthesia, Vancouver General Hospital, and the Faculty of Medicine, University of British Columbia, Vancouver, British Columbia. Presented in part at the Annual Meeting, Western Divisions, Canadian Anaesthetists' Society, April, 1964. 
The tidal volume, minute volume, and vital capacity of these patients were measured with a Wright respirometer. The $\mathrm{pH}, p \mathrm{CO}_{2}, \mathrm{HCO}_{3}^{-}$, and base excess were determined by the micro-Astrup technique. Plasma concentrations of sodium, potassium, and chloride were recorded at suitable intervals. Blood volume was calculated from plasma tágged "with radioactive iodinated human serum albumin (RIHSA), using the Volemetron (Atomium Corporation).

The central venous pressure was determined by visual observation of a column of saline or citrate solution rising in a cerebrospinal fluid (CSF) manometer, transmitted through a No. 16 polyethylene catheter placed in the superior vena cava (SVC), via an antecubital cut-down. Zero was estimated at the level of the right atrium. Arterial blood pressure was taken with a standard arm pressure cuff and a mercury manometer (Tycos).

\section{Results AND Discussion}

The results are presented and discussed from three main aspects: (A) clinical presentations; (B) biochemical changes: acid-base and electrolyte alterations; (C) haemodynamic alterations.

\section{A. Clinical Preseñtations}

Table I gives a clinical summary of four representative patients $\mid$ with refractory hypotension. The majority of these patients were elderly, three of them being

\section{TABLE I}

Clinical Summary of Patients With Refractory Hypotension

\begin{tabular}{|c|c|c|c|c|}
\hline Case No. & 1 (J.L.K.) & 2 (P.N.T.) & 3 (O.B.R.) & 4 (M.P.S.) \\
\hline Sex & $\mathrm{F}$ & $\mathrm{F}$ & $\mathrm{M}$ & $M$ \\
\hline Age & 77 & 33 & 89 & 69 \\
\hline $\begin{array}{l}\text { Primary } \\
\text { diagnosis }\end{array}$ & $\begin{array}{l}\text { Fractured } \\
\text { femur }\end{array}$ & $\begin{array}{l}\text { Septic } \\
\text { abortion }\end{array}$ & Cholecystitis & $\begin{array}{l}\text { Leaking aortic } \\
\text { aneurysm }\end{array}$ \\
\hline Operation & S.P. nail & Curettage & Cholecystectomy & Aortic graft \\
\hline $\begin{array}{l}\text { Aetiology of } \\
\text { hypotension }\end{array}$ & $\begin{array}{l}\text { Blood volume } \\
\text { deficit }\end{array}$ & Septicaemia & $\begin{array}{c}\text { Myocardial } \\
\text { failure }\end{array}$ & $\begin{array}{l}\text { Extengive surgery } \\
\text { with local } \\
\text { vascular } \\
\text { complications }\end{array}$ \\
\hline $\begin{array}{l}\text { Replacement } \\
\text { during } \\
\text { hypotension }\end{array}$ & $\begin{array}{l}1000 \mathrm{ml} . \text { blood } \\
264 \mathrm{mEq} . \mathrm{NaHCO}_{3}\end{array}$ & $\begin{array}{l}1000 \mathrm{ml} . \text { blood } \\
500 \mathrm{ml} \text {. plasma } \\
268 \mathrm{mEq} . \mathrm{NaHCO}\end{array}$ & $\begin{array}{l}500 \mathrm{ml} \text {. blood } \\
166 \mathrm{mEq} \text {. NaHCO}\end{array}$ & $\begin{array}{l}1500 \mathrm{ml} . \text { blood } \\
25 \mathrm{gm} \text {. mannitol } \\
264 \mathrm{mEq} . \mathrm{NaHCO}_{3}\end{array}$ \\
\hline Outcome & Survival & Survival & Survival & Survival \\
\hline
\end{tabular}

77,89 , and 69 years of age, respectively. The hypotension seemed largely traceable to four main pathophysiologic sequences, ${ }^{1}$ often acting together. 'These sequences were:

1. Unrecognized, persisting, blood volume deficit, associated with a coexisting metabolic acidosis and hyponatraemia, as in our patient 1.

2. Circulatory failure associated with invasive infection, as in case 2. 
3. Complicating myocardial failure, as in our patient 3.

4. Extensive surgery followed by local vascular complications, as in patient 4 . These four clinical presentations will now be discussed in more detail.

\section{Unrecognized, Persisting Blood Volume Deficits, with Hyponatraemia and/or Metabolic Acidosis}

Case 1 (Table I). A 77-year-old female with a fractured femur who had had a Smith-Peterson nailing illustrates this type of situation. This patient became hypotensive (B.P. 40/0) four hours after her operation, and remained hypotensive for 12 hours. She appeared in retrospect to have had clear-cut deficits of whole blood or plasma volume at the time the diagnosis of refractory hypotension was made and vasopressor treatment (phenylephrine) begun. Normal circulation was rapidly restored after the administration of additional whole blood ( $1000 \mathrm{ml}$.), and $264 \mathrm{mEq}$. of $\mathrm{NaHCO}_{3}$ was required to correct a coexisting metabolic acidosis and hyponatraemia.

In each patient, the amount of $\mathrm{NaHCO}_{3}$ required to correct a metabolic acidosis has been calculated on the basis of the formula: body wt. in $\mathrm{kg} . \times 0.3 \times$ base excess $=\mathrm{mEq}$. $\mathrm{NaHCO}_{3}$. (We usually give one-half of this amount initially and then follow the biochemical trend before giving the full amount.) This formula was originally suggested by Astrup for the correction of the deficit in the extracellular space. ${ }^{2,3}$ The $\mathrm{NaHCO}_{3}$ preparation is available in 50.0 c.c. ampoules of $44 \mathrm{mEq}$. each.

\section{Infection: Severe Sepsis}

Refractory hypotension followed the abrupt onset of hyperpyrexia in several patients, as case 2 (Table I) demonstrates, with a septicaemia (B-haemolytic enterococcus and Staphylococcus aureus) secondary to septic abortion. Following a curettage this patient developed a temperature of $104^{\circ}$. F. Her blood pressure fell to $30 / 0$, and she remained hypotensive for 5 days. When we saw this patient there was a severe metabolic acidosis present as well as a low plasma sodium concentration. Normal circulation was restored by the administration of $268 \mathrm{mEq}$. of $\mathrm{NaHCO}_{3}, 1000 \mathrm{ml}$. of blood, and $500 \mathrm{ml}$. of plasma. Prior to correction of the acid-base deficit, the administration of hydrocortisone intravenously $(800 \mathrm{mg}$. per day) did not appear to be beneficial in the restoration of circulatory homoeostasis in this patient; nor was it possible to maintain blood pressure at satisfactory levels with the administration of norepinephrine intravenously, even with an ever increasing dosage.

\section{Myocardial Failure}

Patient 3 (Table I) indicates how myocardial failure, in this instance associated with an acute posterior myocardial infarction, may be responsible for refractory hypotension developing in the surgical patient. This instance occurred in an 89-year-old man following cholecystectomy. This patient became cold and sweaty on the fourth postoperative day. His blood pressure dropped from $185 / 110$ to $80 / 40$, and he was hypotensive for 4 days. Before studies were done, the intravenous administration of norepinephrine in increasing concentrations had failed 
to restore circulation. Intravenous digitalization (digitoxin) and also isopropylnorepinephrine (Isuprel $囚$ ) (1:50,000 dilution in 5\% dextrose water) infusion was followed by a progressive fall in the elevated central venous pressure of $22 \mathrm{~cm}$. water and restoration of circulatory homoeostasis. It was possible to discontinue the use of intravenous vasopressors within three hours after intravenous digitalization was begun, and the associated metabolic acidosis was corrected with 166 $\mathrm{mEq}$. of $\mathrm{NaHCO}_{3}$. The mild respiratory acidosis was corrected with intermittent positive pressure respiratory assistance (Bird) by mask. Ventilation became adequate once normal circulation was re-established. This seems to illustrate that patients presenting in refractory hypotension may have an associated hypoventilation. It is easy to forget the respiratory aspects of the patient in hypotension. This patient also received $500 \mathrm{ml}$. of blood.

In patients in the older age group with shock it is possible to demonstrate changes in ST segment depression indicating the presence of myocardial ischaemia during hypotension. With the restoration of pressure and flow at the coronary ostia, these E.C.G. changes are readily reversed.

\section{Local Vascular Complications of Extensive Operations}

Our case 4 (Table I), a 69-year-old rnale, illustrates the type of patient who has undergone extensive surgery (abdominal aortic graft) associated with severe haemorrhage (leaking abdominal aortic aneurysm) and complications of advanced degenerative vascular disease (lower limb ischaemia) and some transient renal failure. Hypotension developed 12 hours after surgery and was of 48 hours' duration. Phenylephrine (Neosynephrine ${ }^{\circledR}$ ) had been started intravenously to maintain some degree of blood pressure. This was only moderately successful. By the time we saw this patient he was shown to have a metabolic acidosis, with hyponatraemia. Eventually $264 \mathrm{mEq} . \mathrm{NaHCO}_{3}$ were required to restore acid-base equilibrium. Hypovolaemia was suspected, on the basis of a low central venous pressure, which did not rise when blood was given. With the administration of $1500 \mathrm{ml}$. of blood the central venous pressure rose by only $1 \mathrm{~cm}$. of water pressure, from 5 to 6 . The arterial blood pressure rose steadily. Because of a significant decrease in urime output, $25 \mathrm{gm}$. of mannitol was also given. Following these therapeutic measures the patient was able to maintain a satisfactory circulation without vasopressor support.

\section{B. Biochemical Changes}

Table II summarizes the electrolyte and acid-base findings in our four representative patients during refractory hypotension.

\section{Electrolyte Alterations}

A low sodium state was the most common single alteration of electrolytes noted. It occurred in each of our four illustrative patients (Table II).

Hyponatraemia (plasma sodium concentration of $130 \mathrm{mEq} / \mathrm{L}$. or lower) may occur frequently in the early postoperative period when dilutional hyponatraemia is very easily produced by water infusion. In several patients a severe dilutional hyponatraemia had been produced by the administration of a continuing intra- 


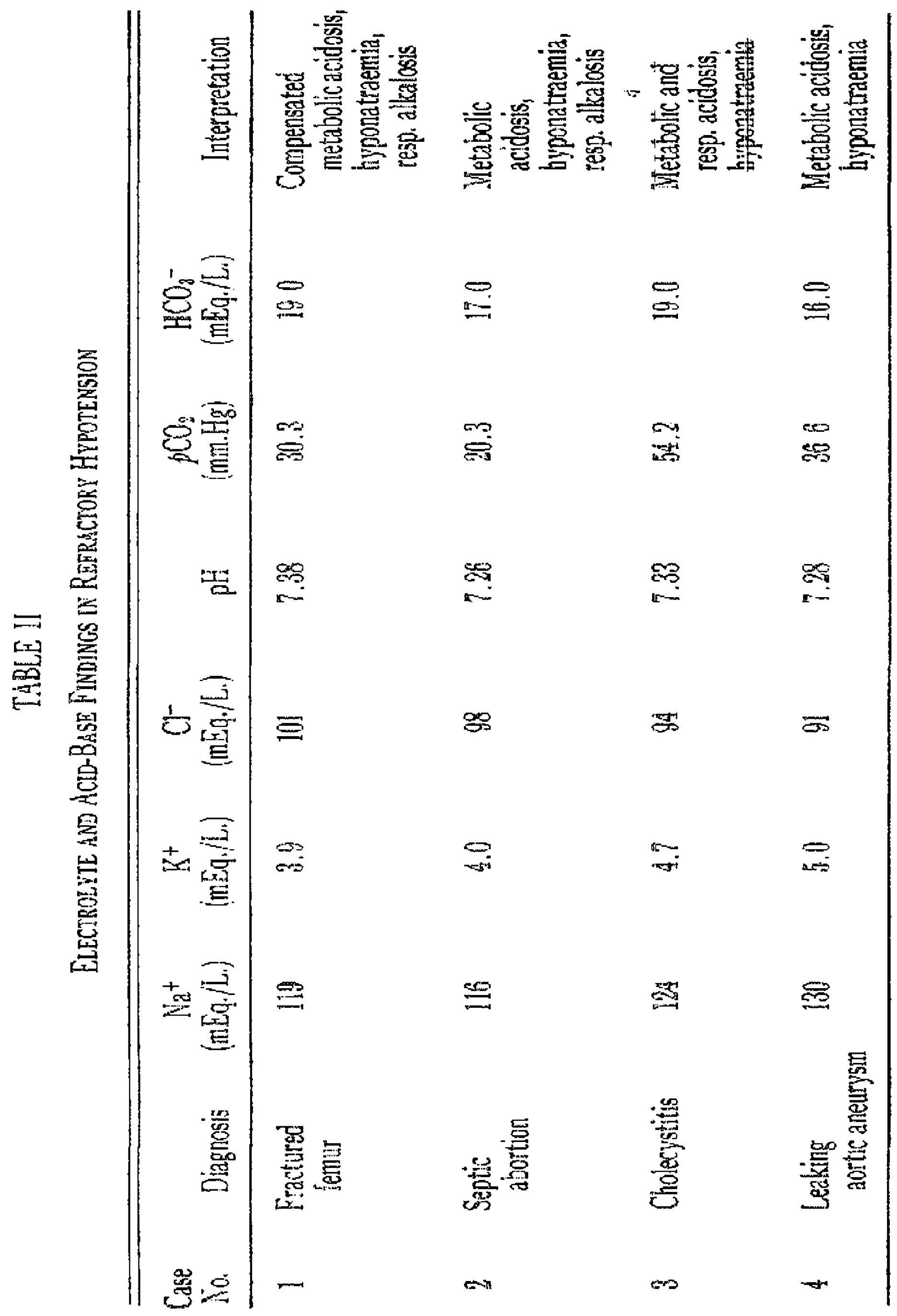


venous infusion of dextrose/water as the vehicle for vasopressors, antibiotics, or corticosteroids. This had occurred particularly in our patient with the septic abortion (in case 2, Table II, the $\mathrm{Na}$ + was $1.16 \mathrm{mEq} . / \mathrm{L}$.).

Dilution and sodium loss remain the two most important factors producing hyponatraemia.

The favourable response of the hyponatraemic patients (all four of our patients) indicates that hyponatraemic patients with refractory hypotension whether $_{\text {w }}$ wot this results from a sodium deficit, will benefit by the administration of concentrated sodium solutions $\left(5 \% \mathrm{NaCl}, \mathrm{NaHCO}_{3}\right)$. If a metabolic acidosis is present as well, which is so often the case in these patients, $\mathrm{NaHCO}_{3}$ is a useful preparation.

\section{Acid-Base Balance}

A metabolic acidosis was the most common coexisting defect found in these patients (Table II). It was usually severe (in three of four patients in Table II) and became progressively worse during periods of low tissue perfusion. This has been referred to as "hypoxic acidosis." $4, \bar{s}$

It is a distinct clinical impression that the correction of acidosis by the administration of base or buffer will not restore normal haemodynamics in the presence of a continuing uncorrected blood volume deficit. With volume restoration, however, the correction of an assuciated metabolic or respiratory acidosis improves myocardial function ${ }^{6}$ (we have seen this by direct visualization of the heart, during open-heart surgery). Correction of acid-base imbalance also permits the discontinuance of vasopressors ${ }^{7}$ and lowers the volume of blood transfusion required in these patients. Intravenous $\mathrm{NaHCO}_{3}$ therapy improved the clinical status of those patients who had a metabolic acidosis.

\section{Haemodynamic Alterations}

Table III summarizes the haemodynamic observations during and after refractory hypotension in our four illustrative patients.

We have found that "spot" blood volume measurements carried out on acutely ill patients with haemorrhage, hypotension, and shock are sometimes difficult to

TABLE III

Haemodynamic Observations during and after Refractory Hypotension

\begin{tabular}{|c|c|c|c|c|c|c|c|}
\hline $\begin{array}{l}\text { Case } \\
\text { No. }\end{array}$ & $\begin{array}{l}\text { Time of } \\
\text { sampling }\end{array}$ & $\begin{array}{c}\text { Body wt. } \\
(\mathrm{kg})\end{array}$ & $\begin{array}{c}\text { Haema- } \\
\text { tocrit } \\
(\%)\end{array}$ & $\begin{array}{c}\mathrm{HBG} \\
(\mathrm{gnl} . / 100 \mathrm{ml} .)\end{array}$ & $\begin{array}{c}\text { Blood } \\
\text { volume } \\
\text { (RIHSA) }\end{array}$ & $\begin{array}{c}\mathrm{CVP}^{\mathrm{C}} \\
\left(\mathrm{cm} . \mathrm{H}_{2} \mathrm{O}\right)\end{array}$ & $\begin{array}{l}\text { Blood volume } \\
\text { as \% of } \\
\text { body wt. }\end{array}$ \\
\hline 1 & $\begin{array}{l}\text { During } \\
\text { After }\end{array}$ & $\begin{array}{l}388 \\
+19\end{array}$ & $\begin{array}{l}42.5 \\
34.5\end{array}$ & $\begin{array}{l}126 \\
13.0\end{array}$ & $\begin{array}{l}2952 \\
3438\end{array}$ & $\frac{0}{5}$ & $\begin{array}{l}7.0 \\
8.5\end{array}$ \\
\hline 2 & $\begin{array}{l}\text { During } \\
\text { After }\end{array}$ & $\begin{array}{l}57.0 \\
57.5\end{array}$ & $\begin{array}{l}36.5 \\
37.0\end{array}$ & $\begin{array}{l}14.6 \\
15.8\end{array}$ & $\begin{array}{l}4700 \\
5200\end{array}$ & $\begin{array}{r}3 \\
11\end{array}$ & $\begin{array}{l}8.3 \\
9.1\end{array}$ \\
\hline 3 & $\begin{array}{l}\text { During } \\
\text { After }\end{array}$ & $\begin{array}{l}568 \\
57.5\end{array}$ & $\begin{array}{l}41.2 \\
39.0\end{array}$ & $\begin{array}{l}12.8 \\
14.0\end{array}$ & $\begin{array}{l}3808 \\
3536\end{array}$ & $2 \cdot 2$ & $\begin{array}{l}6.7 \\
6.1\end{array}$ \\
\hline 4 & $\begin{array}{l}\text { During } \\
\text { After }\end{array}$ & $\begin{array}{l}58.5 \\
590\end{array}$ & $\begin{array}{l}37.0 \\
37.5\end{array}$ & $\begin{array}{l}10.1 \\
11.7\end{array}$ & $\begin{array}{l}4650 \\
4970\end{array}$ & 5 & $\begin{array}{l}8.0 \\
8.4\end{array}$ \\
\hline
\end{tabular}


interpret. This is believed to be due to the fact that while blood is being lost and blood is being given, the equilibration of the albumin tag (RIHSA) is difficult to establish. ${ }^{1}$

We have found it imperative to compare blood volume determinations with the important clinical data on central venous pressure and indices of tissue perfusion, such as capillary blood flow and refill, skin colour and warmth, blood pressure and urine output.

An interesting observation was that patients with severe sepsis were very sensitive to any further reduction in blood volume ${ }^{8}$ and may show a favourable response to overtransfusion (case 2, Table III).

One major concern in treating a patient with refractory hypotension who is suspected of having a blood volume deficit is the threat of overtransfusion and the production of congestive heart failure. This threat is most noticeable in patients with concomitant renal failure or pre-existent cardiopulmonary disease. It is worth remembering, however, that even elderly patients in shock are in point of fact fully as vulnerable to prolonged under-replacement of blood as they are to sudden over-replacement.

Constant or intermittent monitoring of central venous pressure (CVP) is simple and very helpful in the management of these patients and may provide an index for the need of chemical treatment rather than blood. Volume replacement therapy can safely be continued as long as the venous pressure does not show a steady rise, before the arterial blood pressure increase, and thereafter. A rising venous pressure indicates blood-volume overexpansion in relation to myocardial function. In such a case one must either decrease the rate of transfusion or give a cardiotonic agent-for example, a digitalis preparation, isopropyl norepinephrine (Isuprel@), calcium chloride, or calcium gluconate-and correct the acid-base imbalance, depending on the specific clinical indications.

TABLE IV

Useful Chemical Agents IN the

Treatment of Shock

1. $\mathrm{NaHCO}_{3}$

2. Isopropylnorepinephrine

3. Calcium Gluconate

Calcium chloride

4. Cardiac glycosides

5. Antibiotics

Applying this technique, ${ }^{9}$ then, when confronted with a patient in refractory shock, one transfuses with blood, blood substitute, or fluid electrolyte depending on the specific indication until either the CVP or arterial blood pressure rises. If the arterial blood pressure has returned to normal before the CVP exceeds $15 \mathrm{~cm}$. of water, hypovolaemia was in all likelihood the cause of the refractory hypotension. If the $C V P$ rises to above $15 \mathrm{~cm}$. water and the arterial blood pressure remains low, one can then institute chemical therapy (Table IV lists useful chemical agents in the treatment of shock) including buffers for the correction of $\mathrm{pH}$, 
cardiac glycosides, vasodilators, ${ }^{10}$ cardiotonic agents, and antibiotics, knowing that the blood volume is "normal" for the patient. The true efficacy of chemical agents recommended for the treatment of shock can then be evaluated more rationally.

In patients who are on vasopressors, repeated attempts to stop the vasopressor must be made, coupled with energetic blood-volume replacement and correction of electrolyte and acid-base defects.

Isopropyl norepinephrine (Isuprelß) is a useful chemical agent which has perhaps been neglected in clinical practice. In contrast to other vasopressors it increases the blood pressure by virtue of its cardiotonic effect rather than by increasing peripheral resistance, which may be detrimental in the already vasoconstricted shock patient. In fact, in larger doses it is a peripheral vasodilator, which in itself may be of value in the treatment of shock.

When monitoring blood pressure with a vasopressor, thought must always be given to the total dosage and duration; otherwise the net effect must inevitably be a harmful overdose.

It is encouraging to realize that once the pathophysiologic defect is recognized and repaired, patients considered to be in a potentially "irreversible" or refractory hypotensive state may, in fact, show surprising reversibility and survivability. ${ }^{11}$

\section{Summary AND CoNClusions}

1. There appear to be four main clinical postoperative presentations in which patients most commonly have refractory hypotension: (i) those with unrecognized, persisting blood-volume deficit, (ii) those with severe sepsis, (iii) those with complicating myocardial failure, (iv) those who have had extensive surgical procedures with local complications.

2. These patients commonly present with a coexisting metabolic acidosis and/or hyponatraemia.

3. In view of these observations, it is suggested that in the treatment of these patients with refractory hypotension blood and fluid loss be fully replaced. A persisting, unrecognized blood-volume deficit often in fact still exists in these patients. Central venous pressure (CVP) can be a useful guide to this replacement therapy. If during volume replacement the arterial blood pressure rises, before the CVP, then in all likelihood volume deficit hypotension shock existed. If, however, CVP increases steadily and before the arterial blood pressure rises, then the transfusion rate must be decreased and chemical therapy with cardiotonic agents used, in the form of a digitalis preparation, isopropyl norepinephrine, or calcium chloride or gluconate. In either case concurrent correction of the acid-base defect is carried out. Metabolic acidosis and hyponatraemia can be treated effectively with $\mathrm{NaHCO}_{3}$. Appropriate antibacterial therapy is given where indicated.

4. Patients considered to be in a potentially "irreversible" or tefractory hypotensive status may, in fact, show surprising reversibility and survivability, once the pathophysiologic defect is recognized and repaired. 


\section{RÉSUMÉ}

1. Selon toute apparence, il existe quatre principales éventualités cliniques postopératoires où l'on observe chez les malades une hypotension rebelle assez fréquement:

(a) celles où il existe une hypovolémie méconnue;

(b) celles où il s'agit d'une septicémie grave;

(c) celles qui se compliquent d'une défaillance myocardique;

(d) celles où la chirurgie a été extensive, et accompagnée de complications locales.

2. D'ordinaire, on découvre chez ces malades une acidose métabolique et/ou une hyponatrémie coexistante.

3. A la lumière de ces observations, nous suggérons que, pour traiter ces malades présentant une hypotension rebelle, le sang let les pertes de fluides soient totalement remplacés. Souvent, de fait, il persiste une hypovolémie méconnue chez ces malades. Au cours de cette thérapie de remplacement, la pression veineuse centrale (PVC) devient un guide précieux. Si, au cours de cette thérapie de remplacement, la pression artérielle s'élève avant la pression veineuse centrale, alors, selon toute vraisemblance, il s'agit d'un état de choc par hypovolémie. $\mathrm{Si}$, toutefois, la pression veineuse centrale augmente constamment avant que la pression artérielle ne commence à s'élever, il faut alors diminuer la vitesse d'administration des fluides et faire usage de chimiothérapie avec cardiotoniques sous forme de préparation de digitale, isopropyl, norépinéphrine ou du chlorure on du gluconate de calcium. Dans les deux éventualités, il faut faire une correction concomitante de l'équilibre acide-base. L'acidose métabolique et l'hyponatrémie peuvent être traitées de façon efficace, avec des bicarbonates de sodium $\left(\mathrm{NaHCO}_{3}\right.$ ). S'il y a indication, on donnera une médication antibiotique.

4. Des malades que l'on considère dans un état d'hypotension virtuellement irréversible ou rebelle peuvent en fait récupérer de façon surprenante et manifester une bonne vitalité, lorsque le déséquilibre physio-pathologique est diagnostiqué et traité.

\section{ACRNOWLEDGMENTS}

We should like to express our appreciation to Dr. R. E. Creighton and Miss $\mathbb{I}$. Connon for the blood-volume and biochemical determinations in this study.

\section{REFERENCES}

1. SMrth, L. L., \& Moope, F. D. Refractory Hypotension in Man-Is This Irreversible Shock? N. Engl. J. Med. 267: 733-742 (1962).

2. Astrup, $\mathrm{P}$. Acid-Base Studies: $\mathrm{A}$ Technique of Measurement of $\mathrm{pH}, p \mathrm{CO}_{2}$ and $\mathrm{HCO}_{3}$. Lancet i, 1035 (1960).

3. ANDERson, O. S. Acid-Base Studies Using a New Apparatus. Scand. J. Clin. Lab. Invest. 12: $172(1960)$.

4. Clowes, G. H.; Neville, W. E.; SabGa, G.; \& Smibota, Y. Relationship of Oxygen Consumption, Perfusion Rate, and Temperature to Acidosis Associated with Cardiopulmonary Circulatory By-Pass. Surgery 44: 220-239 (1958). 
5. Srmeone, F. A. Shock and Blood Pressure. Surg., Gynec. \& Obst. 108: 740-742 (1959).

6. Thrower, W. B.; DArby, T. D.; \& Aldinger, E. E. Acid-Base Derangements and Myocardial Contractility: Effects as Complications of Shock. Arch. Surg. 82: 56-65 (1961).

7. Campielil, G. S.; Haule, D. B.; Crisp, N. W.; Wen, M. H.; \& Brown, E. B. Depressed Response to Intravenous Sympathicomimetic Agents in Humans during Acidosis. Dis. of Chest 33: 18 (1958).

8. Ebert, R. W. Discussion of Septic Shock. Conf. on Recent Progress and Present Problems in Field of Shock. Walter Reed Arrny Hosp., Wash., D.C. (Dec. 14-17, 1960).

9. Maclean, L. D. Blood Volume Versus Central Venous Pressure in Shock. Surg., Gynec. \& Obst. 118: 594 (1964).

10. Nickerson, M., \& GARTER, S. A. Adrenergic Block in Shock. Canad. J. Biochem. 37 : 1161-1171 (1959).

11. Berger, R. L.; Boyd, T. F.; \& Mancus, P. S. A Pattern of Blood-Volume Responses to Open-Heart Surgery. N. Engl. J. Med. 271: 59-63 (1964). 